\title{
Lymphaticovenular anastomosis for breast cancer-related upper extremity lymphedema: a literature review
}

\author{
Antonio J. Forte ${ }^{1}$, Andrea Sisti ${ }^{1}$, Maria T. Huayllani ${ }^{1}$, Daniel Boczar ${ }^{1}$, Gabriela Cinotto ${ }^{1}$, Pedro Ciudad ${ }^{2}$, \\ Oscar J. Manrique ${ }^{3}$, Xiaona $\mathrm{Lu}^{4}$, Sarah McLaughlin ${ }^{5}$ \\ ${ }^{1}$ Division of Plastic Surgery Mayo Clinic, Jacksonville, FL, USA; ${ }^{2}$ Department of Plastic, Reconstructive and Burn Surgery, Arzobispo Loayza \\ National Hospital, Lima, Peru; ${ }^{3}$ Division of Plastic Surgery, Mayo Clinic, Rochester, Minnesota, USA; ${ }^{4}$ Division of Plastic and Reconstructive \\ Surgery, Yale School of Medicine, New Haven, Connecticut, USA; ${ }^{5}$ Department of Surgery, Mayo Clinic, Jacksonville, FL, USA \\ Contributions: (I) Conception and design: AJ Forte, A Sisti; (II) Administrative support: AJ Forte; (III) Provision of study materials or patients: None; \\ (IV) Collection and assembly of data: A Sisti, MT Huayllani, D Boczar, G Cinotto; (V) Data analysis and interpretation: A Sisti, MT Huayllani, P \\ Ciudad, OJ Manrique, X Lu, S McLaughlin; (VI) Manuscript writing: All authors; (VII) Final approval of manuscript: All authors. \\ Correspondence to: Antonio J. Forte, MD, PhD. Division of Plastic Surgery, Mayo Clinic, 4500 San Pablo Rd, Jacksonville, FL 32224, USA. \\ Email: ajvforte@yahoo.com.br.
}

\begin{abstract}
Breast cancer-related lymphedema is a long-term condition that affects almost half of breast cancer survivors. Clinical studies have looked at the benefits of lymphaticovenular anastomosis (LVA) for the treatment of upper extremities lymphedema after breast cancer, however, there is still controversy if it improves lymphedema. This study aimed to analyze the studies and outcomes related to LVA for breast cancer-related lymphedema. A PubMed/Medline search was performed using "lymphovenous bypass", "upper extremity lymphedema", "arm lymphedema after breast cancer treatment", and "lymphaticovenular anastomosis" as key words. Only English articles reporting outcomes after LVA were included. We found 22 articles that met the inclusion criteria. Positive outcomes were found in 21 studies with an objective volume reduction and subjective symptoms relief after LVA. This literature review concluded that LVA has demonstrated a significant decrease in upper extremity volumes and an improvement in subjectively reporting symptoms in breast cancer-related lymphedema patients.
\end{abstract}

Keywords: Lymphaticovenular anastomosis (LVA); lymphovenous bypass; lymphovenous anastomosis; breast cancer; lymphedema; upper extremity

Submitted Nov 18, 2019. Accepted for publication Mar 17, 2020.

doi: $10.21037 /$ gs.2020.03.41

View this article at: http://dx.doi.org/10.21037/gs.2020.03.41

\section{Introduction}

Lymphedema after breast cancer treatment affects from $9 \%$ to $41 \%$ of patients (1). This implies that more than one in five women who survive breast cancer will develop upper extremity lymphedema (2). This condition involves the upper ipsilateral end to the breast affected by cancer.

Associated risk-factors include age, higher body mass index, advanced disease/pathologic stage, axillary lymph node dissection, chemotherapy, radiotherapy, infection, injury, and history of seroma (3-9). Clinically, the protein- rich lymphatic fluid ends up accumulating in the interstitial spaces, producing a progressive swelling of the upper limbs. These symptoms usually appear within the first 2 years after treatment. Moreover, in long-term follow-up, this disease may result in adverse effects, such as pain, skin changes, fibrosis, deformity, functional disability, loss of sensation, heaviness in the arm, distress, and depression (10-13). Therefore, the high costs related to the management of symptoms and adverse effects during outpatient visits and mental health services have an important economic impact in the society. 
Several surgical and nonsurgical treatments have been proposed to treat this condition $(9,14-17)$. Surgical treatments include ablative and physiologic operations, in which new connections are created to increase the drainage capacity of the lymphatic fluid (18-20). Surgical techniques have evolved becoming more effective and less invasive (21-23). The aim of this review is to analyze the clinical studies published to date about lymphaticovenular anastomosis (LVA, also called lymphovenous bypass) for upper extremities lymphedema after breast cancer treatment.

\section{Methods}

We performed a search on PubMed/Medline using "lymphovenous bypass", "upper extremity lymphedema", "arm lymphedema after breast cancer treatment", and "lymphaticovenular anastomosis" as key words. We included studies describing clinical experience with lymphovenous bypass surgery for upper extremity lymphedema after breast cancer treatment. Papers included were original studies in which LVA was performed for the treatment of lymphedema secondary to breast cancer treatment. Only clinical studies with reports written in English were considered for data extraction; review articles were excluded. Demographic data, lymphedema duration, surgical technique, follow-up time, and outcomes were collected.

The publications were screened manually to identify reports of surgical treatment of upper extremity lymphedema using LVA. Two investigators (the first and the second authors) independently reviewed and extracted data from the papers according to eligibility criteria.

\section{Results}

We found 22 studies from 1977 to 2019 (Table S1). Four were prospective studies (24-27) and 18 were retrospective studies (28-45). Number of patients included ranged from 2 (37) to 95 (31). Lymphedema duration ranged from 6 months (28) to 39 years (41). Campisi lymphedema grading system (46-48) was used in 7 studies $(25,27,37,38,40,41,44)$, while MD Anderson system, based on indocyanine green lymphangiography findings, was used in two $(24,26)$. One study (42) used the grading system described by Cheng (49). One study (45) used a personal grading system based on the severity of the edema, another (36) used a specific grading system based on the circumference comparison between the lymphedema limb and the normal limb, and another (39) used a staging system based on the preoperative indocyanine green lymphangiography findings.

LVA with end-to-end or end-to-side anastomoses was the surgical technique used in 17 studies (24-33,35,38,39,41-43, 45), while 3 studies used microsurgical lymphaticovenous implantation technique $(34,36,40)$. The other 2 studies used LVA with the intravascular stenting method (37) and lymphovenous bypass with sleeve-in anastomosis (44). Postoperative follow-up time ranged from 3 months (28) to 84 months (24).

Upper limb circumference and volume change were the most frequently assessed parameters; however, 1 study also considered any scintigraphic uptake as a positive result (25). Outcomes were positive in 21 of 22 studies, with an average objective regression of arm volume around $30 \%$. Subjective clinical improvement was nearly universal, with only 1 study (25) showing no significant improvements in volume or scintigraphic measurements after LVA in longterm follow-up. However, $50 \%$ of patients in that study had an initial period of relief of the subjective symptoms (25). One study reported lymphangitis in 3 patients as a surgical adverse effect after LVA (45).

The largest patient populations were reported by Krylov et al. (31) (95 patients) and Chang et al. (24) (89 patients). Chang et al. (24) reported overall mean volume differential reduction rates of $33 \%$ at 3 months, $36 \%$ at 6 months, and $42 \%$ at 12 months in patients who underwent LVA due to lymphedema. Mean volume differential reduction rates were $35 \%$ at 2 years and $38 \%$ at 3 years after LVA in 10 followed patients (24).

LVA was performed in patients affected by an early stage of lymphedema. When LVA was performed in patients with late stages of lymphedema (i.e., III or IV), the circumferential reduction rate was not significant, but subjective reporting of the affected extremities as lighter and softer was reported (44).

\section{Discussion}

Lymphedema staging was assessed through different classifications over the years (24,45-50). Campisi classification divided patients with lymphedema into 5 stages (46-48). Stage 1a corresponds to absence of edema; stage 1b, to mild swelling that returns to normal after night rest; stage 2 , to permanent edema that spontaneously regresses with position; stage 3, to permanent edema that does not regress spontaneously; stage 4, to fibrolymphedema, and stage 5 , to elephantiasis with severe extremity deformation (46-48). On the other hand, MD Anderson lymphedema classification 
is based on indocyanine green lymphangiographic findings, dividing the patients into 4 stages: stage 1 refers to many patent lymphatic vessels with minimal patchy dermal backflow; stage 2, to moderate number of patent lymphatic vessels with segmental dermal backflow; stage 3, to few patent lymphatic vessels, with extensive dermal backflow; and stage 4, to no patent lymphatic vessels observed (24). Cheng (49) established their own grading scale, suggesting disease management according to the grade of lymphedema (i.e., 0-IV), which is divided based on the symptoms (ie, reversible, mild, moderate, severe, very severe), circumference differentiation percentage (ie, circumference of the lesioned limb subtracted from the circumference of the healthy limb and divided by the circumference of the healthy limb), and lymphoscintigraphy (i.e., partial or total occlusion). Despite the heterogeneity of classification systems used between studies, most of them reported positive outcomes after LVA [21/22 (95.4\%)].

For several decades, a number of preclinical studies have been conducted in an effort to elucidate the impact of LVA intervention in the upper extremity to alleviate lymphedema. In 1962, Jacobson and Suarez (51) described the possibility of performing an anastomosis between lymphatic vessels and veins in a canine model. Further use of this method in the treatment of early secondary lymphedema was mentioned by Gilbert et al. in a 1976 study also on dogs (52). With this approach, congestive lymphatic fluid can successfully be drained into the cutaneous veins.

In 1977, O'Brien et al. (28) were the first to report a clinical experience using LVA for obstructive lymphedema in humans. In 2000, Koshima et al. (35) described the use of LVA for the treatment of lymphedema in the upper extremities. The results of these preliminary analyses were positive, and have driven the field forward for microsurgerytrained plastic surgeons to address this clinical dilemma.

The most frequently performed technique for the surgical treatment of breast cancer-related lymphedema of upper extremity is LVA with either end-to-end or end-toside anastomosis; however, others have been reported. In 1998, Yamamoto and Sugihara (34) described microsurgical lymphaticovenous implantation, in which multiple collecting lymphatics are implanted into the small vein through modified sleeve anastomotic technique. In 2019, Chung et al. (44) described their experience performing lymphovenous anastomosis with the sleeve-in technique, used when there are no venules of similar diameter to other lymphatic vessels. This technique attaches a lymphatic vessel with the surrounding adventitia into the wall of the venule by about 0.2 to $0.3 \mathrm{~mm}$, using the pull-out suture technique. Indeed nowadays, supermicrosurgery techniques allow anastomosis of vessels at the capillary level with a diameter of 0.3 to $0.8 \mathrm{~mm}$ (35). Controversy still exists regarding the number of anastomoses that would result in significant reductions. Chen et al. (53) proposed their technique by performing between seven to twelve LVA per affected extremity using lymphatic vessels and veins in a range of 0.2 to $0.6 \mathrm{~mm}$.

Krylov et al. (31) were the first to raise concern of intralymphatic pressure. In normal physiology, lymphatic pressure should be lower than venous pressure; consequently, the flow through the anastomosis should be directed in the opposite direction to the desired one. Some surgeons have advocated addressing the problem by performing several LVAs on the same vein, but in the patient affected by lymphedema, the flow is directed in the lymphatic-venous direction due to the pressure in extracellular space from the pressing weight of the accumulated lymphedema. Furthermore, Narushima et al. (37) found that with a high number of LVAs per limb, the mean percentage reduction in the cross-sectional area increased exponentially, while other authors did not find a significant association in long-term follow-up $(27,29,30,45)$.

Lymphatic microsurgery is ideally indicated in early stages, according to the 5-stage Campisi classification $(46-48,54)$. Importantly, microlymphatic surgery is not recommended in primary lymphedema, since the lymphatics are usually hypoplastic (32). Relative contraindications to lymphatic microsurgery include lymphatic-lymph nodal aplasia, diffuse metastatic disease, advanced stage, and no response to conservative therapies.

On the other hand, it is still not clear if breast reconstruction influences risk of lymphedema. Menezes et al. (55) observed that breast reconstruction does not increase the risk of lymphedema in long-term follow-up, while Siotos et al. (56) stated that breast reconstruction is associated with lower rates of lymphedema compared to mastectomy only or breast conserving surgery. This association might be due to several factors, such as a selfselecting population and mechanisms that contribute to prevention of lymphedema.

As with all literature reviews, this study has several limitations. First, there is a general lack of large-volume studies addressing LVA in the upper extremity following breast cancer. Moreover, there was an inability to pool data based on different protocols, varying techniques and measurement of the outcomes for statistical analyses. 
Despite this, we feel that our study reports valuable pooled data, particularly pertaining to overall positive outcomes in LVA in the upper extremity across 21 of the 22 studies identified. Furthermore, our review is limited by the heterogeneity of the patient populations and classification systems used in the included studies, as well as the English language inclusion criteria. As such, there is a potential for bias in interpreting the data reported in each study, the comorbidity data and reporting outcomes over a longperiod of time. Larger, randomized, multicenter studies are warranted to validate the associations found in this review of the literature.

\section{Conclusions}

The results of this review of the literature on LVA for breast cancer-related upper extremity lymphedema demonstrated a significant decrease in upper extremity volumes and improvement in subjective findings of lymphedema in most patients. Importantly, this response was maintained in longterm follow-up. There is evidence to suggest great efficacy in LVA in the upper extremity following breast cancer extirpation.

\section{Acknowledgments}

Funding: This study was supported in part by the Plastic Surgery Foundation, and by the Mayo Clinic Center for Individualized Medicine.

\section{Footnote}

Provenance and Peer Review: This article was commissioned by the Guest Editors (Xiaona Lu, Antonio Jorge Forte) for the series "Lymphedema" published in Gland Surgery. The article was sent for external peer review organized by the Guest Editors and the editorial office.

Conflicts of Interest: The series "Lymphedema" was commissioned by the editorial office without any funding or sponsorship. XL serves as the unpaid editorial board member of Gland Surgery from Aug 2019 to Jul 2021 and served as the unpaid Guest Editor of the series. AJF served as the unpaid Guest Editor of the series. The other authors have no other conflicts of interest to declare.

Ethical Statement: The authors are accountable for all aspects of the work in ensuring that questions related to the accuracy or integrity of any part of the work are appropriately investigated and resolved.

Open Access Statement: This is an Open Access article distributed in accordance with the Creative Commons Attribution-NonCommercial-NoDerivs 4.0 International License (CC BY-NC-ND 4.0), which permits the noncommercial replication and distribution of the article with the strict proviso that no changes or edits are made and the original work is properly cited (including links to both the formal publication through the relevant DOI and the license). See: https://creativecommons.org/licenses/by-nc-nd/4.0/.

\section{References}

1. Chang DW. Lymphaticovenular bypass surgery for lymphedema management in breast cancer patients. Handchir Mikrochir Plast Chir 2012;44:343-7.

2. DiSipio T, Rye $S$, Newman B, et al. Incidence of unilateral arm lymphoedema after breast cancer: a systematic review and meta-analysis. Lancet Oncol 2013;14:500-15.

3. Coriddi M, Khansa I, Stephens J, et al. Analysis of factors contributing to severity of breast cancer-related lymphedema. Ann Plast Surg 2015;74:22-5.

4. McLaughlin SA. Lymphedema: separating fact from fiction. Oncology (Williston Park) 2012;26:242-9.

5. McLaughlin SA, Wright MJ, Morris KT, et al. Prevalence of lymphedema in women with breast cancer 5 years after sentinel lymph node biopsy or axillary dissection: objective measurements. J Clin Oncol 2008;26:5213-9.

6. McLaughlin SA, Wright MJ, Morris KT, et al. Prevalence of lymphedema in women with breast cancer 5 years after sentinel lymph node biopsy or axillary dissection: patient perceptions and precautionary behaviors. J Clin Oncol 2008;26:5220-6.

7. Tsai RJ, Dennis LK, Lynch CF, et al. Lymphedema following breast cancer: The importance of surgical methods and obesity. Front Womens Health 2018;3.

8. Ribeiro Pereira ACP, Koifman RJ, Bergmann A. Incidence and risk factors of lymphedema after breast cancer treatment: 10 years of follow-up. Breast 2017;36:67-73.

9. Gillespie TC, Sayegh HE, Brunelle CL, et al. Breast cancer-related lymphedema: risk factors, precautionary measures, and treatments. Gland Surg 2018;7:379-403.

10. Teo I, Novy DM, Chang DW, et al. Examining pain, body image, and depressive symptoms in patients with lymphedema secondary to breast cancer. Psychooncology 2015;24:1377-83. 
11. Cornelissen AJM, Kool M, Lopez Penha TR, et al. Lymphatico-venous anastomosis as treatment for breast cancer-related lymphedema: a prospective study on quality of life. Breast Cancer Res Treat 2017;163:281-6.

12. Mehrara BJ, Zampell JC, Suami H, et al. Surgical management of lymphedema: past, present, and future. Lymphat Res Biol 2011;9:159-67.

13. Penha TR, Botter B, Heuts EM, et al. Quality of Life in Patients with Breast Cancer-Related Lymphedema and Reconstructive Breast Surgery. J Reconstr Microsurg 2016;32:484-90.

14. Garza R 3rd, Skoracki R, Hock K, et al. A comprehensive overview on the surgical management of secondary lymphedema of the upper and lower extremities related to prior oncologic therapies. BMC Cancer 2017;17:468.

15. McLaughlin SA, DeSnyder SM, Klimberg S, et al. Considerations for Clinicians in the Diagnosis, Prevention, and Treatment of Breast Cancer-Related Lymphedema, Recommendations from an Expert Panel: Part 2: Preventive and Therapeutic Options. Ann Surg Oncol 2017;24:2827-35.

16. Shaitelman SF, Cromwell KD, Rasmussen JC, et al. Recent progress in the treatment and prevention of cancer-related lymphedema. CA Cancer J Clin 2015;65:55-81.

17. Merchant SJ, Chen SL. Prevention and management of lymphedema after breast cancer treatment. Breast J 2015;21:276-84.

18. Suami H, Chang DW. Overview of surgical treatments for breast cancer-related lymphedema. Plast Reconstr Surg 2010;126:1853-63.

19. Granzow JW. Lymphedema surgery: the current state of the art. Clin Exp Metastasis 2018;35:553-8.

20. Nagase T, Gonda K, Inoue K, et al. Treatment of lymphedema with lymphaticovenular anastomoses. Int J Clin Oncol 2005;10:304-10.

21. Granzow JW, Soderberg JM, Kaji AH, et al. Review of current surgical treatments for lymphedema. Ann Surg Oncol 2014;21:1195-201.

22. Chang DW, Masia J, Garza R, 3rd, et al. Lymphedema: Surgical and Medical Therapy. Plast Reconstr Surg 2016;138:209S-18S.

23. Scaglioni MF, Fontein DBY, Arvanitakis M, et al. Systematic review of lymphovenous anastomosis (LVA) for the treatment of lymphedema. Microsurgery 2017;37:947-53.

24. Chang DW, Suami H, Skoracki R. A prospective analysis of 100 consecutive lymphovenous bypass cases for treatment of extremity lymphedema. Plast Reconstr Surg
2013;132:1305-14.

25. Damstra RJ, Voesten HG, van Schelven WD, et al. Lymphatic venous anastomosis (LVA) for treatment of secondary arm lymphedema. A prospective study of 11 LVA procedures in 10 patients with breast cancer related lymphedema and a critical review of the literature. Breast Cancer Res Treat 2009;113:199-206.

26. Torrisi JS, Joseph WJ, Ghanta S, et al. Lymphaticovenous bypass decreases pathologic skin changes in upper extremity breast cancer-related lymphedema. Lymphat Res Biol 2015;13:46-53.

27. Chang DW. Lymphaticovenular bypass for lymphedema management in breast cancer patients: a prospective study. Plast Reconstr Surg 2010;126:752-8.

28. O'Brien BM, Sykes P, Threlfall GN, et al. Microlymphaticovenous anastomoses for obstructive lymphedema. Plast Reconstr Surg 1977;60:197-211.

29. O'Brien BM, Das SK. Microlymphatic surgery in management of lymphoedema of the upper limb. Ann Acad Med Singapore 1979;8:474-80.

30. Gong-Kang H, Ru-Qi H, Zong-Zhao L, et al. Microlymphaticovenous anastomosis for treating lymphedema of the extremities and external genitalia. J Microsurg 1981;3:32-9.

31. Krylov VS, Milanov NO, Abalmasov KG, et al. Reconstructive microsurgery in treatment of lymphoedema in extremities. Int Angiol 1985;4:171-5.

32. O'Brien BM, Mellow CG, Khazanchi RK, et al. Longterm results after microlymphaticovenous anastomoses for the treatment of obstructive lymphedema. Plast Reconstr Surg 1990;85:562-72.

33. Koshima I, Kawada S, Moriguchi T, et al. Ultrastructural observations of lymphatic vessels in lymphedema in human extremities. Plast Reconstr Surg 1996;97:397-405; discussion 406-7.

34. Yamamoto Y, Sugihara T. Microsurgical lymphaticovenous implantation for the treatment of chronic lymphedema. Plast Reconstr Surg 1998;101:157-61.

35. Koshima I, Inagawa K, Urushibara K, et al. Supermicrosurgical lymphaticovenular anastomosis for the treatment of lymphedema in the upper extremities. J Reconstr Microsurg 2000;16:437-42.

36. Yamamoto Y, Horiuchi K, Sasaki S, et al. Follow-up study of upper limb lymphedema patients treated by microsurgical lymphaticovenous implantation (MLVI) combined with compression therapy. Microsurgery 2003;23:21-6.

37. Narushima M, Mihara M, Yamamoto Y, et al. The 
intravascular stenting method for treatment of extremity lymphedema with multiconfiguration lymphaticovenous anastomoses. Plast Reconstr Surg 2010;125:935-43.

38. Yamamoto T, Yamamoto N, Numahata T, et al. Navigation lymphatic supermicrosurgery for the treatment of cancerrelated peripheral lymphedema. Vasc Endovascular Surg 2014;48:139-43.

39. Auba C, Marre D, Rodriguez-Losada G, et al. Lymphaticovenular anastomoses for lymphedema treatment: 18 months postoperative outcomes. Microsurgery 2012;32:261-8.

40. Poumellec MA, Foissac R, Cegarra-Escolano M, et al. Surgical treatment of secondary lymphedema of the upper limb by stepped microsurgical lymphaticovenous anastomoses. Breast Cancer Res Treat 2017;162:219-24.

41. Winters H, Tielemans HJP, Hameeteman M, et al. The efficacy of lymphaticovenular anastomosis in breast cancer-related lymphedema. Breast Cancer Res Treat 2017;165:321-7.

42. Engel H, Lin CY, Huang JJ, et al. Outcomes of Lymphedema Microsurgery for Breast Cancer-related Lymphedema With or Without Microvascular Breast Reconstruction. Ann Surg 2018;268:1076-83.

43. Pereira N, Lee YH, Suh Y, et al. Cumulative Experience in Lymphovenous Anastomosis for Lymphedema Treatment: The Learning Curve Effect on the Overall Outcome. J Reconstr Microsurg 2018;34:735-41.

44. Chung JH, Baek SO, Park HJ, et al. Efficacy and patient satisfaction regarding lymphovenous bypass with sleevein anastomosis for extremity lymphedema. Arch Plast Surg 2019;46:46-56.

45. Filippetti M, Santoro E, Graziano F, et al. Modern therapeutic approaches to postmastectomy brachial lymphedema. Microsurgery 1994;15:604-10.

Cite this article as: Forte AJ, Sisti A, Huayllani MT, Boczar D, Cinotto G, Ciudad P, Manrique OJ, Lu X, McLaughlin S. Lymphaticovenular anastomosis for breast cancer-related upper extremity lymphedema: a literature review. Gland Surg 2020;9(2):539-544. doi: 10.21037/gs.2020.03.41
46. Campisi C. Lymphoedema: modern diagnostic and therapeutic aspects. Int Angiol 1999;18:14-24.

47. Campisi C, Boccardo F, Zilli A, et al. Peripheral lymphedema: new advances in microsurgical treatment and long-term outcome. Microsurgery 2003;23:522-5.

48. Campisi C, Davini D, Bellini C, et al. Lymphatic microsurgery for the treatment of lymphedema. Microsurgery 2006;26:65-9.

49. Patel KM, Lin CY, Cheng MH. A Prospective Evaluation of Lymphedema-Specific Quality-of-Life Outcomes Following Vascularized Lymph Node Transfer. Ann Surg Oncol 2015;22:2424-30.

50. Yamamoto T, Yamamoto N, Doi K, et al. Indocyanine green-enhanced lymphography for upper extremity lymphedema: a novel severity staging system using dermal back flow patterns. Plast Reconstr Surg 2011;128:941-7.

51. Jacobson JH 2nd, Suarez EL. Microvascular surgery. Dis Chest 1962;41:220-4.

52. Gilbert A, O'Brien BM, Vorrath JW, et al. Lymphaticovenous anastomosis by microvascular technique. Br J Plast Surg 1976;29:355-60.

53. Chen WF. How to Get Started Performing Supermicrosurgical Lymphaticovenular Anastomosis to Treat Lymphedema. Ann Plast Surg 2018;81:S15-20.

54. Campisi C, Eretta C, Pertile D, et al. Microsurgery for treatment of peripheral lymphedema: long-term outcome and future perspectives. Microsurgery 2007;27:333-8.

55. Menezes MM, Bello MA, Millen E, et al. Breast reconstruction and risk of lymphedema after mastectomy: A prospective cohort study with 10 years of follow-up. J Plast Reconstr Aesthet Surg 2016;69:1218-26.

56. Siotos C, Sebai ME, Wan EL, et al. Breast reconstruction and risk of arm lymphedema development: A metaanalysis. J Plast Reconstr Aesthet Surg 2018;71:807-18. 


\begin{tabular}{|c|c|c|c|c|c|c|c|c|c|}
\hline Author & Year & Type of study & Number of patients, demographic data & Lymphedema duration & Lymphedema grading system & Surgical technique & Follow-up time & Outcomes & Notes \\
\hline O'Brien BM (28) & 1977 & Retrospective study & 22 & $\begin{array}{l}6 \text { months- } 21 \text { years } \\
\text { (average: } 8.9 \text { years) }\end{array}$ & NR & LVA, number of anastomoses: $1-7$ & 3-20 months & $\begin{array}{l}\text { The excess volume was reduced by an average of } 19 \%, 1-7 \mathrm{~cm} \text { decrease in the } \\
\text { circumference }\end{array}$ & $\begin{array}{l}\text { Incidence of cellulitis dropped from } 56 \% \text { to } 13 \% \\
\text { postoperatively }\end{array}$ \\
\hline O'Brien BM (29) & 1979 & Retrospective study & 23 & NR & NR & LVA & NR & NR & $\begin{array}{l}\text { No correlation was found between the number of LVAs } \\
\text { and the final reduction in volume }\end{array}$ \\
\hline Gong-Kang $\mathrm{H}(30)$ & 1981 & Retrospective study & 2 & NR & NR & LVA (end-to-end or end-to-side fashion) & Up to 12 months & Circumference reduction. Decrease of clinical symptoms & The surgeries were performed under epidural anesthesia \\
\hline Krylov VS (31) & 1985 & Retrospective study & 95 & NR & NR & LVA (end-to-end or end-to-side fashion) & NR & NR & $\begin{array}{l}\text { Intralymphatic pressure measurements were taken in the } \\
\text { course of Iymphangiography and intraoperatively }\end{array}$ \\
\hline O'Brien BM (32) & 1990 & Retrospective study & 46 & NR & NR & LVA & NR & 25 patients (54\%) had a volume reduction. The average reduction was $34 \%$ & $\begin{array}{l}\text { Anastomosis at the wrist had a dramatic permanent effect } \\
\text { in reduction of hand edema in the vast majority of patients }\end{array}$ \\
\hline Filippetti M (45) & 1994 & Retrospective study & 25 & NR & $\begin{array}{l}\text { Personal classification in } 3 \text { grades } \\
(45)\end{array}$ & LVA & 6-18 months & $\begin{array}{l}10 \text { patients showed tair or good results at } 18 \text { months. Three patients presented } \\
\text { with lymphangitis as a surgicala adverse effect }\end{array}$ & $\begin{array}{l}\text { A correlation between results and number of anastomoses } \\
\text { were fond. Tho anastomoses caused good results i the } \\
\text { short and medium term }\end{array}$ \\
\hline Koshimal (33) & 1996 & Retrospective study & $\begin{array}{l}6 \text { female, mean (SD) age: } 56.5(8.7) \text { years, } \\
5 \text { left arm and } 1 \text { right arm }\end{array}$ & $\begin{array}{l}\text { Mean (range): } \\
70.8(11-137) \text { months }\end{array}$ & Severe-moderate (arbitrary) & LVA & $\begin{array}{l}17 \text { months or more } \\
\text { (average } 25.5 \text { months) }\end{array}$ & $\begin{array}{l}\text { The circumference of the arms decreased maximally by } 2-9 \mathrm{~cm} \text { (average } 5.3 \mathrm{~cm} \text { ). } \\
\text { The rata of ofreoperative versus postoperative excess of the amms decreased by } \\
25-94.7 \% \text { (average } 65.7 \% \text { ) }\end{array}$ & $\begin{array}{l}\text { In the postoperative scenario, no correlation was found } \\
\text { between the prooperative duration of edema and excess } \\
\text { circumference }\end{array}$ \\
\hline Yamamoto Y (34) & 1998 & Retrospective study & $\begin{array}{l}5 \text { upper extremitites in } 5 \text { female patients, } \\
3 \text { right extremitis and } 2 \text { teft texterintitis; } \\
\text { age range: } 57-72 \text { years }\end{array}$ & $\begin{array}{l}\text { Mean (range): } \\
9.4(1-18 \text { years) }\end{array}$ & NR & 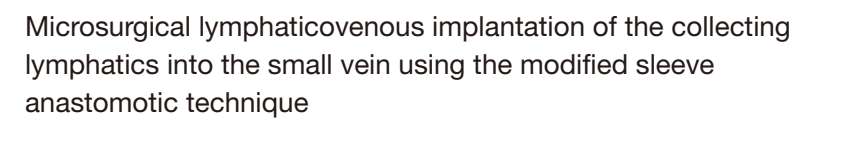 & $\begin{array}{l}\text { Average } 1 \text { year and } \\
5 \text { months } 99 \text { months- } \\
2 \text { years) }\end{array}$ & 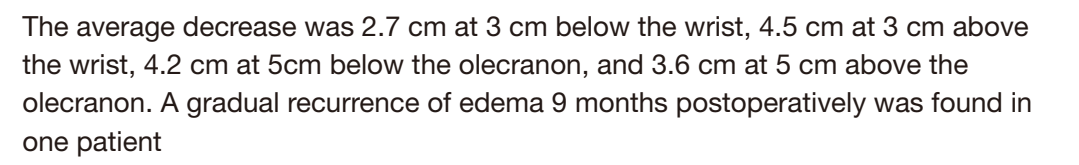 & $\begin{array}{l}\text { A greater reduction in the circumference of the dorsum } \\
\text { of hand and forearm than the upper arm was found in all } \\
\text { patients }\end{array}$ \\
\hline Koshimal (35) & 2000 & Retrospective study & 12, mean age: 57 years & Mean: 8.2 years & Severe-moderate (arbitrary) & 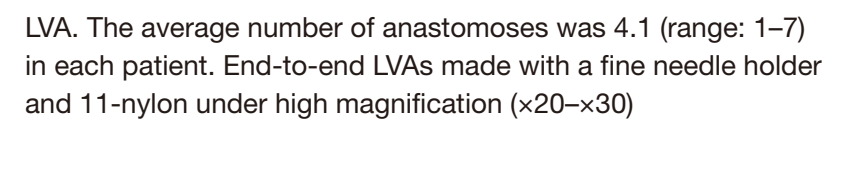 & $\begin{array}{l}\text { Average: } 2.2 \text { years } \\
\text { (from } 1 \text { month-6 years) }\end{array}$ & $\begin{array}{l}\text { The average decrease in iricumference was } 4.1 \mathrm{~cm}(47.3 \% \text { of the preoperative } \\
\text { excoss circumference of the forearm) }\end{array}$ & 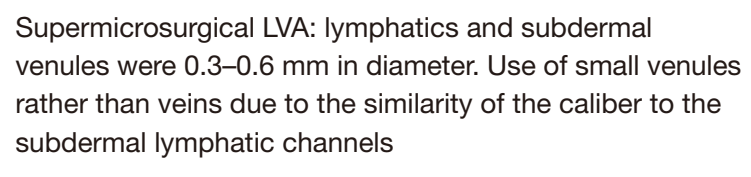 \\
\hline Yamamoto Y (36) & 2003 & Retrospective study & 18 females; age range: $47-80$ years & $\begin{array}{l}\text { Mean (range): } \\
7.1(1-23) \text { years }\end{array}$ & $\begin{array}{l}\text { Average enlargement of edema } \\
\text { circumferencece (AEEE), ocomparing } \\
\text { the affected and non-affected limb. } \\
\text { Patients were classified into } 3 \\
\text { groups (severe, moderate, or mild) } \\
\text { according to AEE findings }\end{array}$ & 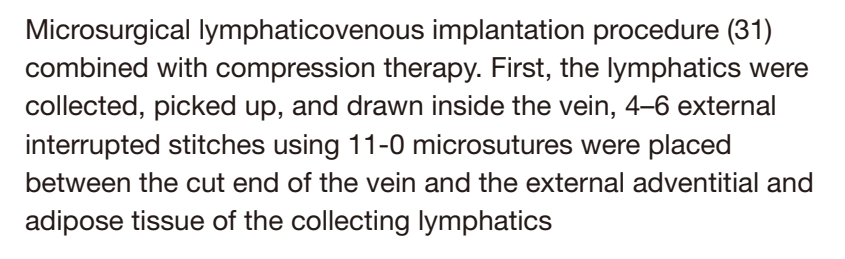 & $\begin{array}{l}\text { Average: } 24 \text { months } \\
\text { (12-72 months) }\end{array}$ & $\begin{array}{l}77.8 \% \text { of patients presented excellent or good results. Reduction of more than } \\
50 \% \text { of the edema circumfrerence at etither the distal or proximal site after treatment }\end{array}$ & $\begin{array}{l}\text { Compression therapy with elastic bandage was continued } \\
\text { in the postoperative period }\end{array}$ \\
\hline Damstra RJ (25) & 2009 & Prospective study & $\begin{array}{l}10 \text { female, mean (range) age: } \\
58.7 \text { (46-68) years }\end{array}$ & $\begin{array}{l}\text { Mean (range): } \\
5.3(3-14) \text { years }\end{array}$ & Campisi (46-48) & 11 LVA procedures & Mean: 8 years & 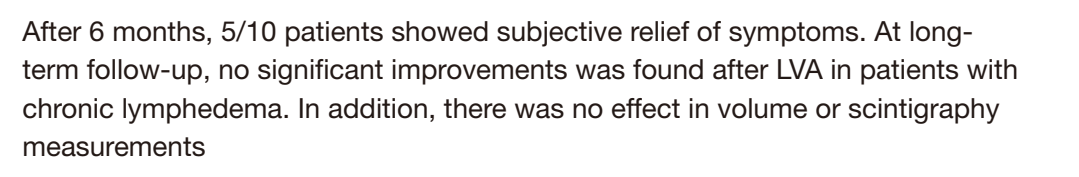 & The authors considered any uptake a positive result \\
\hline Narushima M (37) & 2010 & Retrospective study & 2 & NR & Campisi (46-48) & $\begin{array}{l}\text { LVA with intravascular stenting method. In each of the } 2 \text { upper } \\
\text { extremities, } 4 \text { and } 6 \text { anastostomoses were performed. Enddo-side } \\
\text { LWA at the elbu, and end-to-side and end-to-end LVA at the } \\
\text { wrist were performed }\end{array}$ & NR & Cross-sectional area girth reduction & $\begin{array}{l}\text { Increasing the number of LAs per limb decreased the } \\
\text { average percentage in the cross-sectional area }\end{array}$ \\
\hline Chang DW (27) & 2010 & Prospective study & 20, mean age: 54 years & $\begin{array}{l}\text { Mean (range): } \\
4.8(1-17) \text { years }\end{array}$ & Campisi (46-48) & $\begin{array}{l}\text { LVA (generally performed end-to-end). The mean (range) number } \\
\text { of bypasses performed was } 3.5(2-5)\end{array}$ & Mean: 18 months & 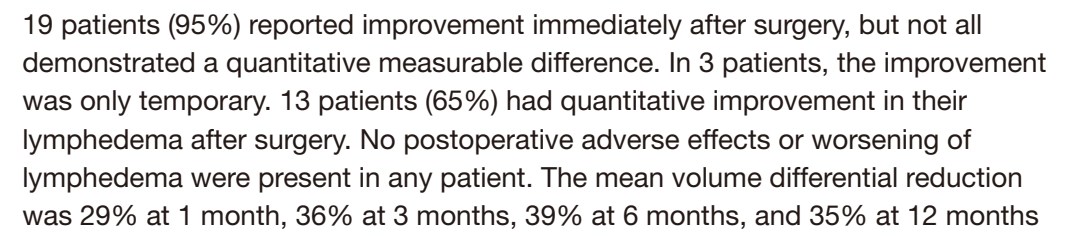 & \\
\hline Auba C (39) & 2012 & Retrospective study & 7 & NR & Campisi (46-48) & 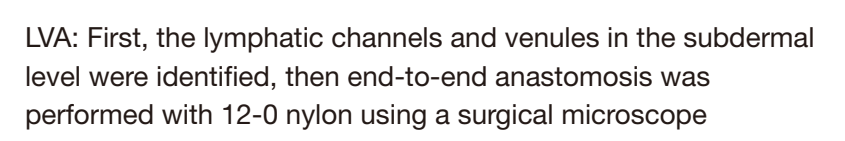 & 24 months & The mean (SD) perimeter reduction was $0.85(1.06) \mathrm{cm}$ & $\begin{array}{l}\text { Most patients presented an objective regression of } \\
\text { lymphedema }\end{array}$ \\
\hline Chang DW (24) & 2013 & Prospective study & $\begin{array}{l}89 \text { (46 lett and } 43 \text { right upper extremitiess; } \\
\text { mean age: } 5 \text { yearss maen (range) } \mathrm{BM}: \text { : } \\
30(20-51) \text { kg/m }\end{array}$ & $\begin{array}{l}\text { Mean (range): } \\
\text { 3.5(1-10) years }\end{array}$ & MD Anderson (24) & LVA & $\begin{array}{l}\text { Mean (range): } \\
30.4(3-84) \text { months }\end{array}$ & 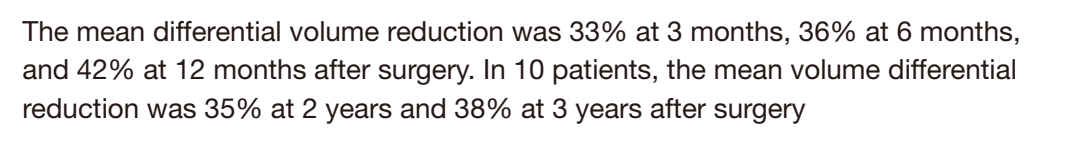 & $\begin{array}{l}\text { Absence of adverse effects or worsening of Iymphedema } \\
\text { after surgery during the study }\end{array}$ \\
\hline Yamamoto T (38) & 2014 & Retrospective study & 3 & NR & $\begin{array}{l}\text { Staging based on the preoperative } \\
\text { ICG lymphography (56) }\end{array}$ & LVA using 11-0 or 12-0 nylon sutures & NR & $\begin{array}{l}\text { Lymphedema indices decreased in all limbs post-surgery compared with } \\
\text { preoperative Iymphedema indices. Absence of any postoperative adversse effects }\end{array}$ & $\begin{array}{l}\text { Intraoperative microscopic ICG Iymphography enhanced } \\
\text { lymphatic vessels }\end{array}$ \\
\hline Torrisi JS (26) & 2015 & Prospective study & 6 female & NR & MD Anderson (24) & LVA & 6 months & 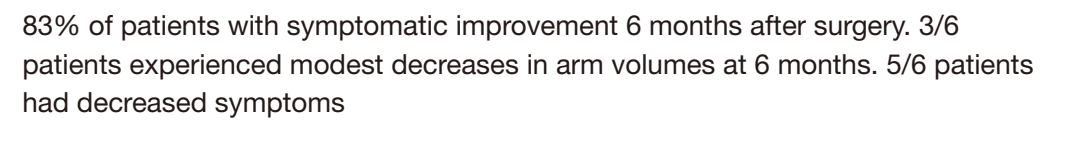 & 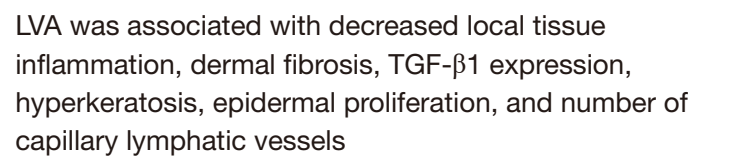 \\
\hline Winters $\mathrm{H}(41)$ & 2017 & Retrospective study & 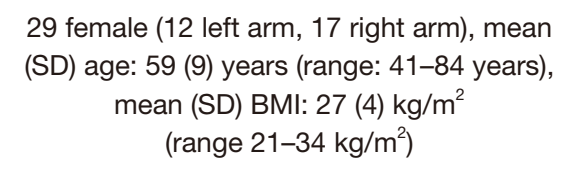 & $\begin{array}{c}\text { Mean (SD): } 9(7.3) \text { years } \\
\text { (range: } 2-39 \text { years) }\end{array}$ & Campisi (46-48) & $\begin{array}{l}\text { LVA: 1-3 anastomoses were created and shunt patency was } \\
\text { confirmed using ICG }\end{array}$ & 12 months & 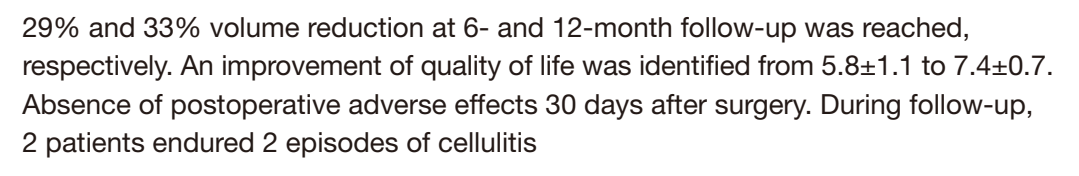 & $\begin{array}{l}\text { The functionality score decreased from } 2.2 \text { to } 1.8 \text {, the } \\
\text { appearance score from } 2.6 \text { to } 1.1 \text {, the symptoms score } \\
\text { from } 2.8 \text { to } 1.8 \text {, and the mood score from } 2.7 \text { to } 1.5\end{array}$ \\
\hline Poumellec MA (40) & 2017 & Retrospective study & $\begin{array}{l}\text { 31, mean (SD) age: } 64(11) \text { years } \\
\text { (range: } 38-65 \text { years) }\end{array}$ & $\geq 12$ months & Campisi (46-48) & 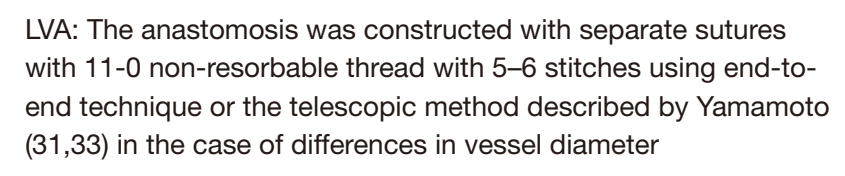 & $\begin{array}{l}34 \text { months } \\
\text { (mean:12.8 months) }\end{array}$ & 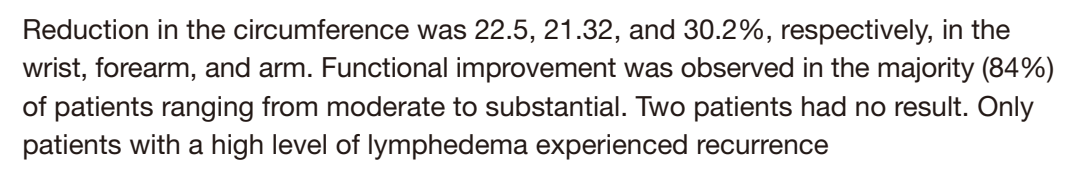 & $\begin{array}{l}\text { The procedure was performed under local-regional } \\
\text { anesthesia (axillary lockk), without an arm tourniquet }\end{array}$ \\
\hline Engel $\mathrm{H}(42)$ & 2018 & Retrospective study & $\begin{array}{l}27 \text { (23 did not receive microsurgical breast } \\
\text { reconstructio and } 4 \text { underentr } \\
\text { microsurgical breast reconstruction) }\end{array}$ & $\begin{array}{c}\text { Mean (SD): } 31.3(11.4) \\
\text { months (range 8.4- } \\
120.5 \text { months) }\end{array}$ & Cheng (49) & $\begin{array}{l}\text { LVA in aside-to-end or end-to-end fashion with a 11-0 nylon } \\
\text { suture }\end{array}$ & $\begin{array}{l}\text { Mean (SD): } 19.1 \text { (5.3) } \\
\text { months (range 5.7- } \\
62.8 \text { months) }\end{array}$ & 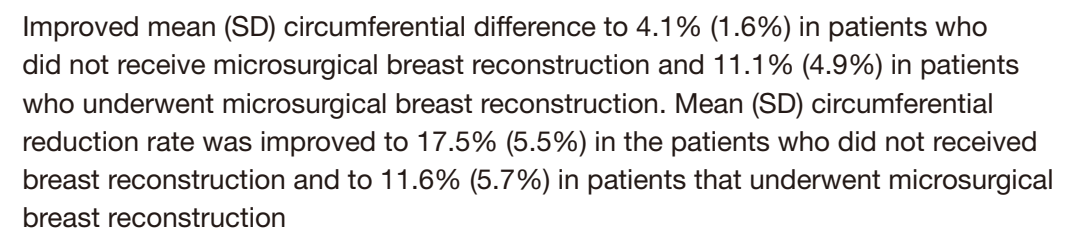 & $\begin{array}{l}\text { The re-exploration rate was } 16.9 \% \text { ( }(n=21) \text {, and the overall } \\
\text { adverse effect rate was 8.1\% }(n=10) \text {. Flap losses did not } \\
\text { occur }\end{array}$ \\
\hline Pereira N (43) & 2018 & Retrospective study & 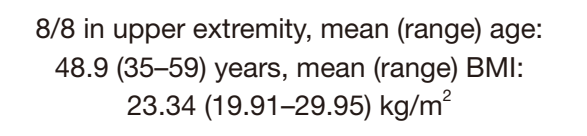 & $\begin{array}{l}\text { Mean (range): } \\
4.61 \text { (2-9.25) years }\end{array}$ & NR & $\begin{array}{l}\text { LVA. Mean (range) number of LVA per upper extremity was } \\
\text { 3.75 } \\
96.1(1-6) \text {, mean (range) time per LVA was }\end{array}$ & $\begin{array}{l}\text { Mean (range): } \\
27.4(3-84) \text { months }\end{array}$ & $\begin{array}{l}\text { Symptoms improved in all patients. Statistically significant quantitative } \\
\text { improvement in percentage of excess volume and postoperative mean volume }\end{array}$ & $\begin{array}{l}\text { Preoperative mean (range) number of cellulitis episodes } \\
\text { per year was } 1.3(0-3) \text {, decreasing to o episodes after } \\
\text { surgery }\end{array}$ \\
\hline Chung JH (44) & 2019 & Retrospective study & $\begin{array}{l}8 \text { patients ( } 5 \text { left and } 3 \text { right, Mean age: } \\
51 \text { years, Mean BMl: } 23 \mathrm{~kg} / \mathrm{m}^{2}\end{array}$ & 4 years & Campisi (46-48) & LVA with the sleeve-in technique & NR & 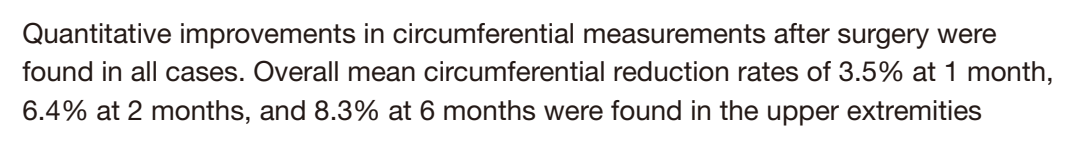 & 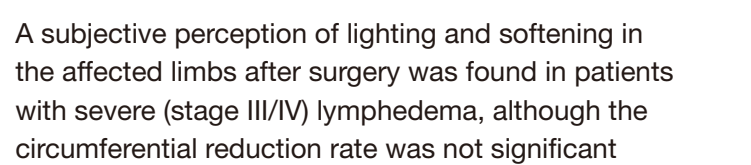 \\
\hline
\end{tabular}

